\title{
SEGMENTASI DAN POLA PERILAKU PENGGUNA FACEBOOK (Studi pada mahasiswa Universitas Muhammadiyah Malang)
}

\author{
Imam Hariyadi \\ Universitas Muhamadiyah Malang \\ E-mail: Tamhariyadi3@gmail.com
}

\begin{abstract}
The purpose of this study was to determine the characteristics and behaviour patterns among facebook users at Students University of Malang. This descriptive type of research used the sample of 100 respondents. A non-probability sampling technique used judgmental sampling. The scale was based on the Likert measurement and this analysis include: the validity and reliability. The analysis of the data obtained used a variable frequency distribution analysis consisting of Demographic (gender, income level), psychographic (activities, interests, opinions) and behaviour (benefits, attitudes). The results of the analysis of the distribution of the respondents classify based on the frequency of demographic, psychographic, and behaviour which they claim that face-book provides entertainment as an alternative to in their spare time. Information obtained, such as the latest news both locally and internationally, information on lectures, job listings, buying and selling. They also interact or communicate with the community group.
\end{abstract}

Keywords: Frequency Distribution Analysis, Behaviour Patterns, Characteristics

\section{PENDAHULUAN}

Kemajuan teknologi yang serba moderen saat ini ternyata juga menyebabkan kemajuan cara berfikir manusia untuk memanfaatkan hasil teknologi tersebut, salah satunya adalah melalui media internet. Di internet bisa mengetahui dan memperoleh apapun yang diinginkan dengan cara singkat. Jejaring sosial adalah struktur sosial yang terdiri dari elemen-elemen individual atau organisasi. Jejaring menunjukan jalan di mana mereka berhubungan karena kesamaan sosialitas, mulai dari mereka yang dikenal sehari-hari.

Facebookmerupakan salah satu situs jejaring sosial yang sangat popular di dunia. Facebook adalah situs web jaringan sosial dimana para pengguna dapat bergabung dalam komunitas seperti kota, kerja, sekolah, dan daerah untuk melakukan koneksi dan berinteraksi dengan orang lain. Orang atau pengguna facebook dapat menambahkan teman-teman mereka, mengirim pesan, dan mem- perbarui profil pribadi agar orang lain dapat melihat tentang dirinya (Wikipedia; diakses maret, 7, 2012). Sejak 2 februari 2012, menurut data statistik dan sosial bakers terbaru. Indonesia menduduki peringkat ketiga 43,06 juta setelah Amerika 155,7 juta dan India 43,49 juta di Dunia dalam pemakaian jejaring facebook (Budi Prasetiyo; maret, 7, 2012).

Seperti yang sudah dijelaskan sebelumnya, fungsi facebook sekarang bukan hanya menjadi situs jejaring pertemanan saja, tetapi sudah bertambah menjadi salah satu media yang digunakan untuk memasarkan atau mempromosikan produk, dan produk yang paling banyak adalah produk fashion, mulai dari pakaian, topi, sepatu, sampai perhiasan atau asesoris yang lain. Setiap kita yang mempunyai akun, tidak jarang kita melihat fotofoto yang di-upload oleh teman kita dan foto-foto itu tidak hanya foto mereka sendiri, tapi terkadang juga foto-foto produk yang mereka tawarkan. 
Menurut Kamus Besar Bahasa Indonesia karakteristik adalah ciri-ciri khusus atau mempunyai sifat khas sesuai dengan perwatakan tertentu dan bawaan seseorang yang menentukan berbagai karakteristik yang disebut temperamen. Berbagai teori pemikiran dari karakteristik tumbuh untuk menjelaskan berbagai kunci karakteristik manusia. Karakteristik diartikan sebagai ciri-ciri individu yang terdiri dari geografi, demografi, psikografi, dan perilaku.

Perilaku konsumen online di Indonesia menarik untuk terus dicermati. Pengguna internet Indonesia banyak menyumbang perkembangan beberapa situs jaringan sosial dunia, seperti facebook. Pengguna internet Indonesia semakin lama semakin banyak karena mendapat kemudahan dan kenyamanan dimana-mana, antara lain dengan perangkat handphone cerdasnya, membuat para pemilik situs dari luar negeri juga para penyedia perangkat keras melirik Indonesia sebagai pasar berprospek. Perilaku konsumen online yang beragam macamnya ini menarik untuk terus dicermati. Karakteristik konsumen yang jelas dapat digunakan oleh para wirausahawan berbasis teknologi informasi untuk mengembangkan bisnisnya dijalur ini.

Pola penggunaan jejaring sosial dikalangan remaja dapat dipengaruhi oleh keluarga, lingkungan, dan karakteristik individu remaja. Remaja yang memiliki latar belakang ekonomi menengah ke atas dapat dengan mudah mengakses jejaring sosial baik melalui telepon genggam atau fasilitas internet yang tersedia, baik di rumah, sekolah dan warung internet. Menjalin hubungan yang erat dan harmonis dengan teman sebaya sangatlah penting pada masa remaja. Pengaruh teman sebaya pada sikap, pembicaraan, minat, penampilan, dan perilaku lebih besar daripada pengaruh keluarga.

Demikian halnya dengan jejaring sosial, informasi jejaring sosial yang diperoleh remaja melalui teman sebaya dapat mempengaruhi pola penggunaan jejaring sosial oleh remaja. Pola perilaku penggunaan pada penelitian ini adalah cara atau tindakan yang biasanya dilakukan mahasiswa dalam menggunakan facebook. Pola perilaku tersebut, terdapat beberapa hal perlu diteliti antara lain, intensitas penggunaan, frekuensi penggunaan, tempat menggunakan, dan motif penggunaan.
Mahasiswa Universitas Muhammadiyah Malang merupakan salah satu pengguna facebook untuk berbagai macam kebutuhan disela aktivitasnya. Facebook selain dijadikan alat berkomunikasi juga dijadikan alat untuk melakukan jual beli transaksi on-line dalam memenuhi kebutuhannya. Mahasiswa beranggapan bahwa facebookmerupakan situs yang digemari oleh banyak orang. Berdasarkan pemaparan permasalahan yang telah diuraikan sebelumnya, maka perumusan masalah pada penelitian ini adalah bagaimana karakteristik dan pola perilaku Pengguna facebook dikalangan mahasiswa Universitas Muhammadiyah Malang. Sedangkan tujuan penelitian dalam studi ini yang pertama adalah mengetahui karakteristik pengguna facebook di kalangan mahasiswa UMM, kedua adalah mengetahui pola perilaku pengguna facebook di kalangan mahasiswa UMM.

\section{TINJAUANPUSTAKA}

Hasil penelitian yang dilakukan oleh Tobing (2010) dengan judul, pola penggunaan facebook di kalangan mahasiswa Universitas Sumatera Utara. Penelitian ini menggunakan teknik analisis data tabel tunggal untuk mengetahui pola penggunaan facebook di kalangan mahasiswa. Hasil penelitian menunjukkan bahwa respon mahasiswa Universitas Sumatera Utara terhadap situs jejaring sosial Facebook sangat baik. Mereka menyatakan bahwa situs Facebook memberikan hiburan dan sebagai alternatif lain dalam mengisi waktu luang. Hal tersebut didapat dari berbagai aplikasi serta fasilitas yang disediakan di dalam situs, seperti: Wall, up-date status, chat room, message, dan game.

Responden menyatakan bahwa banyak sekali informasi yang didapat memalui situs Facebook, seperti: Berita-berita terbaru baik lokal maupun internasional, jadwal kegiatan yang akan dan berlangsung, informasi mengenai perkuliahan, lowongan pekerjaan, jual beli, dan lain sebagainya. Bahwa motif mahasiswa USU dalam mengakses Facebook adalah, untuk medapatkan informasi antar sesama pengguna dan memiliki account di Facebook, menjalin hubungan dengan orang lain 
dan sebagai sarana untuk pelepasan emosi (relaksasi tubuh). Kebutuhan dalam mengakses yaitu, Mencari informasi serta kegiatan para pengguna lain, ingin mengetahui jadwal acara di wilayah pengguna, serta berita-berita terbaru lainnya.

Kombinasi antara penghargaan dan kesulitan dapat membuat pengalaman online dapat memiliki jangkauan dari sangat menyenangkan sampai sangat mengecewakan. Dengan adanya keseimbangan antara tantangan dan keahlian pengguna akan mengalami kepuasan dan hiburan, dimana keseimbangan online dapat membantu dalam kesenangan konsumen terhadap media internet. Menurut Hanson (2000) perilaku konsumen internet menunjukan bahwa pengguna berhubungan langsung dengan informasi sebenarnya dengan banyak karakter dan kecenderungan manusia yang sama seperti yang mereka lakukan di dunia nyata.

Sedangkan menurut Kotler dan Armstrong (2001) menyatakan bahwa para pengguna media internet yang lebih muda cenderung menggunakan internet sebagai hiburan dan sosialisasi, tetapi 45 persen pengguna yang berusia 40 tahun lebih memfokuskan pemakain internet untuk investasi dan masalah-masalah yang lebih serius. Misalnya, 24 persen orang berusia 50 sampai 64 menggunakan internet sebagai keperluan investasi dibandingkan dengan hanya 3 persen orang yang berusia 25 sampai 29 tahun dan hanya 5 persen pengguna diatas 65 tahun pengguna internet, 42 persen dari pengguna itu telah melakukan pembelian sesuatu secara on-line.

Selanjutnya mengenai karakteristik adalah ciri khas seseorang dalam meyakini, bertindak ataupun merasakan. Berbagai teori pemikiran dari karakteristik tumbuh untuk menjelaskan berbagai kunci karakteristik manusia. Variabel-variabel utama dalam mensegmentasikan pasar konsumen adalah (Kotler \& Amstrong 2008), yaitu a) Geografis. yaitu membag pasar menjadi unit-unit geografis yang berbeda-beda seperti negara bagian, kabupaten, kota, atau pemukiman, b) Demografis atau upaya membagi pasar menjadi sejumlah kelompok berdasarkan variabel-variabel seperti usia, gender, ukuran keluarga, siklus hidup keluarga, pendapatan, pekerjaan, pendidikan, agama, ras, dan kebangsaan, c) Psikografis, Yaitu upaya membagi pembeli, menjadi kelompok-kelompok yang berbeda berdasarkan kelompok sosial, gaya hidup atau karakteristik kepribadian, d) Segmentasi perilaku membagi kelompok-kelompok berdasarkan ilmu pengetahuan, sikap, pemakaian, atau tanggapan mereka terhadap sebuah produk.

Pola penggunaan merupakan kecenderungan seseorang untuk menggunakan suatu fasilitas yang telah ada sesuai dengan fungsi dan kegunaanya dengan seharusnya. Tentu saja sesuai kalau kita menggunakan sesuatu dengan kegunaan yang dimilikinya, tapi hal ini sudah dikesampingkan oleh beberapa orang yang cenderung keluar dari fungsi awal fasilitas yang telah diberikan, dalam hal ini Facebook sebagai fungsi Social Networking. Banyak orang yang tidak mengunakan situs jejaring sosial ini sesuai dengan dampak postif nya, tetapi belakangan ini penggunaannya cenderung lebih ke ke arah yang bersifat negatif.

\section{METODE PENELITIAN}

Penelitian dilakukan di Kampus Universitas Muhammadiyah Malang, yang berada di Jl. Raya Tlogomas 246 Malang. Jenis penelitian ini bersifat deskriptif, data yang digunakan dalam penelitian ini adalah data dari hasil pengisian kuisioner yang di distribusikan kepada responden mengenai informasi tentang karakteristik dan pola perilaku pengguna facebook.

Populasi dalam penelitian ini adalah para mahasiswa Universitas Muhammadiyah Malang, baik laki-laki maupun perempuan yang menggunakan Facebook. Sedangkan Sampel yang diambil dalam penelitian ini yaitu sebanyak 100 mahasiswa, baik laki-laki maupun perempuan yang menggunakan Facebook. Keputusan ini dilandasi oleh pendapat Roscoe dalam Widayat (2004) yang mengatakan bahwa pada setiap penelitian, ukuran sampel berkisar antara 30 sampai 500 responden. Selanjutnya, yang mendasari banyaknya responden berjumlah 100 adalah pendapat Fraenkel dan Wallen dalam (Widayat, 2004) yang mengatakan bahwa besarnya sampel minimum untuk penelitian yang bersifat deskriptif yaitu sebanyak 100 responden. 
Peneliti menggunakan teknik nonprobability samplingdalam memilih informan-informannya. Teknik nonprobabilitysampling terdiri dari beberapa macam teknik sampling secara umum, kemudian dikhususkan menggunakan judgement sampling.

Judgement sampling adalah sampel yang dipilih berdasarkan penilaian terhadap beberap karakteristik responden yang sesuai dengan penelitian ini. Pada penelitian ini peneliti memberikan kuisioner off-line kepada mahasiswa Universitas Muhammadiyah Malang yang aktif menggunakan facebook, dalam hal aktif disini yaitu sudah membuka dan menggunakan facebook.

Teknik analisis data yang digunakan dalam penelitian ini yaitu tabulasi frekuensi, yang digunakan untuk menjawab rumusan masalah tentang karakteristik dan pola perilaku pengguna facebook. Tabulasi frekuensi dilakukan dengan mengelompokkan data dengan cara mentabulasikan data yang diperoleh. Tabulasi frekuensi merupakan salah satu ukuran dalam statistik deskriptif yang menunjukkan nilai distribusi data penelitian yang memiliki kesamaan kategori. Frekuensi suatu data distribusi penelitian dinyatakan dengan ukuran absolut (f) atau populasi (\%). Penyajian statistik deskriptif yang menggunakan ukuran frekuensi dapat menggunakan tabel numerik atau grafik (Irianto dan Supomo, 2002).

\section{HASIL PENELITIAN DAN PEMBAHASAN}

Hasil penelitian yang telah dilakukan dengan menyebarkan 100 kuesioner dari jumlah 100 responden yaitu mahasiswa Universitas Muhammadiyah Malang yang menggunakan facebook sebagai sampel diperoleh diskripsi mengenai karakteristik responden, sebagai berikut a) Jenis Kelamin Responden paling banyak adalah wanita yaitu sebanyak 64 responden atau $64 \%$ dan 36 responden atau $36 \%$ adalah pria. Hasil tersebut dapat membuktikan bahwa jenis kelamin wanita merupakan kelompok responden yang lebih banyak mengunakan facebook disela aktivitasnya apabila dibandingkan dengan kelompok responden pria. Hal tersebut dikarenakan kelompok responden tersebut selalu berupaya untuk menggunakan media facebook untuk menambah relasi atau teman mereka. b) Jumlah pendapatan per-Bulan Responden, dibagi menjadi tiga kelompok responden dan jumlah pada masing-masing jumlah kiriman per bulan.

Mahasiswa Universitas Muhammadiyah Malang yang menggunakan facebookyang paling banyak adalah mempunyai jumlah pendapatan perbulan yaitu sebesar Rp. 500.000,-- Rp. 1.000.000,yaitu sebesar 62 responden atau $62 \%$. Hasil tersebut menunjukkan bahwa responden dalam penelitian ini lebih banyak kelas menengah ke atas mengikuti standar kategorisasi Bank dunia kriteria penggolongan pengeluaran yang digunakan responden. c) Lama Akses Dalam Sehari Responden, yaitu mahasiswa Universitas Muhammadiyah Malang menunjukkan minat responden untuk menggunakan fasilitas facebook, yang menggunakan facebook sebanyak 72 responden atau $72 \%$ mengakses dalam sehari yaitu selama 1-3 jam/akses dan sebanyak 3-5 jam/akses dengan $28 \%$. Hasil tersebut menunjukkan bahwa selama ini sebagian besar responden lama mengakses dalam sehari yaitu selama 1-3 jam/ hari, lamanya akses tersebut menunjukkan tingkat minat responden terhadap keberadaan facebook untuk memenuhi berbagai kebutuhan jalinan pertemanan yang dilakukan. d) Tingkat Keseringan Responden Menggunakan Facebook, yaitu mahasiswa Universitas Muhammadiyah Malang yang menggunakan facebookyang paling banyak tingkat keseringan dalam melakukan akses facebook yaitu sebanyak 5-6 kali/minggu dengan jumlah responden sebesar 49 responden atau 49\%. Hasil tersebut menunjukkan bahwa tingkat keseringan para responden tersebut dapat memberikan gambaran atas besarnya minat responden terhadap keberadaan facebook. e) Diikaitkan dengan tempat responden dalam menggunakan facebook maka mahasiswa Universitas Muhammadiyah Malang yang menggunakan facebook dapat diketahui bahwa sebagian besar responden menggunakan facebook di rumah/kost yaitu sebesar 50 responden atau 50\%. 
Hasil tersebut menunjukkan bahwa tempat atau lokasi tersebut benar-benar memberika kenyamanan dalam melakukan akses facebook. Sehingga akses yang dilakukan sesuai dengan keinginan atau harapan para responden. Mengenai tujuan menggunakan facebook para responden yaitu mahasiswa Universitas Muhammadiyah Malang yang menggunakan facebook dapat diketahui bahwa tujuan paling banyak responden yaitu untuk mencari informasi sebanyak 64 responden atau $64 \%$. Hasil tersebut menunjukkan bahwa responden disini untuk mencari informasi tentang belanja berbagai jenis produk, lowongan pekerjaan dan lain-lain dapat menciptakan minat untuk menggunakan facebook. Kemudian perasaan Setelah Mengunakan Facebook, dapat mencerminkan tingkat kepuasan responden terhadap fasilitas yang ditawarkan oleh facebook, dan jumlah untuk masing-masing perasaan para responden terhadap facebook. Mahasiswa Universitas Muhammadiyah Malang yang menggunakan facebook yang paling banyak menyatakan puas yaitu sebesar 82 responden atau $82 \%$. Adanya perasaan puas tersebut menunjukkan minat responden terhadap berbagai fasilitas dan keunggulan yang ditawarkan sehingga tetap menggunakan facebook sebagai media komunikasi.

Deskripsi jawaban responden dapat menggambarkan tanggapan responden atas kuesioner yang telah diberikan kepada mahasiswa Universitas Muhammadiyah Malang yang menggunakan facebook yaitu mengenai Karakteristik Dan Pola Perilaku Pengguna Facebook (Studi pada mahasiswa Universitas Muhammadiyah Malang). Untuk mengetahui deskripsi jawaban responden tersebut maka secara lengkap dapat diuraikan yang pertama Aktivitas $X_{1}$ yaitu Tanggapan responden mengenai variabel aktivitas (aktivity) dapat diketahui melalui empat indicator yang prtama anggapan responden atas pernyataan bahwa melakukan chating menggunakan facebook $\left(\mathrm{X}_{1.1}\right)$. Menunjukkan bahwa responden yang menyatakan sangat setuju sebanyak 3 (3\%), sebanyak 67 atau $67 \%$ menyatakan setuju dan responden yang menyatakan netral sebanyak 30 (30\%) responden. Dengan demikian dapat disimpulkan bahwa se- bagian besar responden menyatakan setuju bahwa melakukan chatingmenggunakan facebook. Hasil tersebut dapat membuktikan bahwa responden lebih memilih facebook untuk melakukan chating dibandingkan dengan menggunakan fasilitas yang lain.

Mengenai tanggapan responden atas pernyataan mengenai menggunakan facebook saya update status $\left(\mathrm{X}_{1.2}\right)$. Menunjukkan bahwa tempat parkir yang rapi menurut responden yang menyatakan sangat setuju sebanyak 4 (4\%), sebanyak 64 atau $64 \%$ menyatakan setuju dan responden yang menyatakan netral sebanyak 32 (32\%) responden. Hasil tersebut menunjukkan bahwa sebagian besar responden menyatakan setuju bahwa menggunakan facebooksaya update status. Dengan demikian dapat dikatakan bahwa para responden selalu aktif untuk menggunakan facebook termasuk untuk melakukan updatestatus.

Responden menanggapi atas pernyataan bahwa upload foto disaat menggunakan faceboook $\left(\mathrm{X}_{1.3}\right)$. Menunjukkan bahwa responden yang menyatakan sangat setuju sebanyak 4 (4\%), sebanyak 69 atau 69\% menyatakan setuju dan responden yang menyatakan netral sebanyak 27 (27\%) responden. Dengan demikian dapat disimpulkan bahwa sebagian besar responden menyatakan setuju menanggapi pernyataan tersebut, yaitu upload foto disaat menggunakan faceboook. Hasil itu dapat membuktikan bahwa para responden selalu melakukan upload foto agar pertemanan yang dilakukan dapat terjalin lebih erat.

Tanggapan responden atas pernyataan mengenai berbelanja menggunakan facebook $\left(\mathrm{X}_{1.4}\right)$. Menunjukkan bahwa responden yang menyatakan sangat setuju sebanyak 6 (6\%), sebanyak 73 atau $73 \%$ menyatakan setuju dan responden yang menyatakan netral sebanyak 21 (21\%) responden. Hasil tersebutmenyatakan bahwa sebagian besar responden menyatakan setuju menanggapi pernyataan bahwa berbelanja menggunakan facebook. Dengan demikian dapat disimpulkan bahwa selama ini para responden menggunakan fasilitas facebook untuk melakukan proses transaksi atas produk atau barang yang diinginkan. 
Tanggapan responden mengenai variabel minat (interest) dapat diketahui melalui dua indikator yaitu, Tanggapan responden atas pernyataan mengenai sering berkomunikasi dengan komunitasnya menggunakan facebook $\left(\mathrm{X}_{2.1}\right)$. Menunjukkan bahwa responden yang menyatakan sangat setuju sebanyak 8 (8\%), sebanyak 67 atau $67 \%$ menyatakan setuju dan responden yang menyatakan netral sebanyak 25 (25\%) responden. Berdasarkan hasil tersebut dapat disimpulkan bahwa sebagian besar responden menyatakan setuju bahwa berkomunikasi dengan komunitasnya menggunakan facebook. Dari hasil tersebut dapat membuktikan bahwa selama ini para responden selalu berupaya untuk menjaga hubungan baik melalui fasilitas facebook terutama untuk pertemanan dengan para komunitas mereka.

Mengenai tanggapan responden atas pernyataan mengenai Facebook media yang sering saya pergunakan dalam berinteraksi di dunia maya $\left(\mathrm{X}_{2.2}\right)$. Menunjukkan bahwa responden yang menyatakan sangat setuju sebanyak 6 (6\%), sebanyak 65 atau $65 \%$ menyatakan setuju dan responden yang menyatakan netral sebanyak 28 (28\%) responden sedangkan sebanyak 1 responden atau $1 \%$ menyatakan tidak setuju. Hasil tersebut menunjukkan bahwa sebagian besar responden menyatakan setuju bahwa Facebook media yang sering dipergunakan dalam berinteraksi di dunia maya. Dengan demikian dapat disimpulkan bahwa para responden selalu menggunakan media facebook untuk berinteraksi dunia maya mengingat berbagai fasilitas yang ditawarkan oleh media tersebut.

Kemudian Opini yakni tanggapan responden mengenai variabel opini (opinion) dapat diketahui melalui dua indikator. Tanggapan responden atas pernyataan mengenai Facebook sebagai media yang tepat untuk berinteraksi $\left(\mathrm{X}_{3.1}\right)$. Menunjukkan bahwa responden yang menyatakan sangat setuju sebanyak 6 (6\%), sebanyak 66 atau $66 \%$ menyatakan setuju dan responden yang menyatakan netral sebanyak 28 (28\%) responden. Berdasarkan hasil tersebut dapat disimpulkan bahwa sebagian besar responden menyatakan setuju bahwa Facebook sebagai media yang tepat untuk berinteraksi. Hasil tersebut dapat membuktikan bahwa selama ini para responden menyatakan bahwa facebook menjadi pilihan utama untuk melakukan interaksi antar teman. Responden menanggapi atas pernyataan mengenai Dalam berbelanja di dunia maya facebook media yang tepat $\left(\mathrm{X}_{3.2}\right)$. Menunjukkan bahwa responden yang menyatakan sangat setuju sebanyak 7 (7\%), sebanyak 64 atau 64\% menyatakan setuju dan responden yang menyatakan netral sebanyak 29 (29\%) responden. Hasil tersebut menunjukkan bahwa sebagian besar responden menyatakan setuju bahwa dalam berbelanja di dunia maya facebook media yang tepat. Dengan demikian dapat dikatakan bahwa selama ini para responden selalu menggunakan facebook untuk memenuhi kebutuhan akan produk yang diinginkan.

Adapun tanggapan responden mengenai variabel perilaku dapat diketahui melalui tiga indikator, Tanggapan responden atas pernyataan mengenai mendapatkan banyak teman setelah menggunakan facebook $\left(\mathrm{X}_{4.1}\right)$. Menunjukkan bahwa responden yang menyatakan sangat setuju sebanyak 6 (6\%), sebanyak 64 atau $64 \%$ menyatakan setuju dan responden yang menyatakan netral sebanyak 30 (30\%) responden. Berdasarkan hasil tersebut dapat disimpulkan bahwa sebagian besar responden menyatakan setuju bahwa mendapatkan banyak teman setelah menggunakan facebook. Hasil tersebut dapat membuktikan bahwa selama ini para responden banyak diuntungkan melalui fasilitas yang ditawarkan oleh media facebook tersebut.

Responden memberikan tanggapan atas pernyataan mengenai sering menggunakan facebook disela aktivitas sehari - hari $\left(\mathrm{X}_{4.2}\right)$. Menunjukkan bahwa responden yang menyatakan sangat setuju sebanyak 6 (6\%), sebanyak 67 atau $67 \%$ menyatakan setuju dan responden yang menyatakan netral sebanyak 27 (27\%) responden. Hasil tersebut menunjukkan bahwa sebagian besar responden menyatakan setuju bahwa sering menggunakan facebook disela aktivitas sehari - hari. Dengan demikian dapat disimpulkan bahwa para responden selalu menggunakan fasilitas facebook untuk mendukung aktivitas yang dilakukan. 
Tanggapan responden atas pernyataan sikap terhadap facebook menjadi pertimbangan untuk menggunakan facebook $\left(\mathrm{X}_{4.3}\right)$. Menunjukkan bahwa responden yang menyatakan sangat setuju sebanyak 9 (9\%), sebanyak 69 atau $69 \%$ menyatakan setuju dan responden yang menyatakan netral sebanyak 22 (22\%) responden. Dengan demikian dapat disimpulkan bahwa sebagian besar responden menyatakan setuju menanggapi pernyataan bahwa sikap terhadap facebook menjadi pertimbangan untuk menggunakan facebook. Hasil tersebut dapat membuktikan menurut responden selalu memiliki sikap yang positif terhadap keberadaan fasilitas facebook sehingga mereka tetap menggunakan facebook disela aktivitas.

\section{SIMPULAN}

Berdasarkan dari hasil analisis dan pembahasan pada bab sebelumnya maka dapat diketahui karakteristik dan pola perilaku pengguna faebook pada mahasiswa Universitas Muhammadiyah Malang. Adapun kesimpulan yang dapat diambil adalah yang pertama respon mahasiswa Universitas Muhammadiyah Malang terhadap situs facebook sangat baik. Mereka menyatakan bahwa situs facebook memberikan hiburan sebagai alternatif lain dalam mengisi waktu luang. Hal tersebut di dapat dari berbagai aplikasi serta fasilitas yang disediakan di dalam situs, seperti: $U p$-date status, chatting, upload foto. Banyak sekali informasi yang didapat memalui situs facebook, seperti: Berita-berita terbaru baik lokal maupun internasional, informasi mengenai perkuliahan, lowongan pekerjaan, jual beli.

Mahasiswa Universitas Muhammadiyah Malang juga melakukan interaksi berkomunikasi dengan para komunitas atau grup mereka dalam menggunakan facebook. Motif mahasiswa Universitas Muhammadiyah Malang dalam mengakses facebook adalah, untuk medapatkan informasi antar sesama pengguna facebook, melakukan transaksi online dan sebagai sarana untuk menambah atau memperbnyak teman. Kebiasaan mengakses para mahasiswa Universitas Muhammadiyah Malang rata-rata selama 1-3 jam setiap hari dan 5
-6 kali/minggu yang dilakukan dilakukan di kost/ rumah. Selain itu responden sebagian besar merasa puas atas semua fasilitas facebook sehingga mahasiswa Universitas Muhammadiyah Malang tetap menggunakan media facebook dalam aktivitas sehari-hari.

Beberapa saran sebagai berikut, satu yaitu saran bagi Perusahaan Online, yakni sebaiknya perusahaan memberikan fasilitas khusus dalam proses transaksi berbelanja. Hasil dari penelitian ini responden menggunakan faebook untuk bertransaksi online (Berbelanja). Apabila disediakan fasilitas khusus pengguna dapat memenuhi kebutuhan konsumen untuk belanja online dan juga bisa menarik calon pengguna baru untuk melakukan transaksi belanja secara online. Yang kedua, bagi Pihak Lain yakni dalam hal ini adalah kalangan akademisi yang berminat untuk melanjutkan penelitian ini diharapkan untuk menyempurnakannyayaitu dengan menggunakan variabel lain dalam karakteristik dan pola perilaku serta penambahan jumlah sampel yang diambil. Selain itu juga diharapkan untuk menggunakan alat analisis yang berbeda dalam melakukan analisis terhadap karakteristik dan pola perilaku dengan harapan penelitian ini dapat lebih berkembang.

\section{DAFTAR PUSTAKA}

Effendy, Onong Uchajana. 2004. Ilmu, Teori dan Filsafat Komunikasi; citra Aditya Bhakti, Bandung.

Ghozali, Imam. 2005. Analisis Multivariate dengan Program SPSS. Badan Penerbit Universitas Diponegoro, Semarang

Hanson, Ward.,2000, Pemasaran Internet, Salemba Empat, Jakarta.

Irianto, Agus. 2006. Statistik Konsep Dasar dan Aplikasinya. Kencana: Jakarta.

Kotler, Philip, dan Keller, Kevin Lane. 2008. Manajemen Pemasaran, edisi 12, jilid 1, PT Indeks, Jakarta.

Kuncoro, M, 2001. Metode Riset untuk Bisnis dan Ekonomi: Bagaimana Meneliti dan menulis Tesis. 
Malhotra, k, Naresh. 2010. Riset Pemasaran Pendekatan Terapan. Indeks Kelompok Gramedia, Jakarta.

Nasution, Z, 1990. Teknologi Komunikasi dan Perspektif: Latar Belakang dan Perkembangannya, Fakultas Ekonomi Universitas Indonesia, Jakarta.

Nugroho J, Setiadi, 2003, Perilaku Konsumen Konsep dan Implikasi untuk Strategis dan Penelitian Pemasaran, edisi 1, Prenada Media, Jakarta.

Peter, J. Paul dan, Olson, Jerry C. 2000, Costumer Behavior,Perilaku Konsumen dan Strategi Pemasaran; edisi 4, jilid 1, Erlangga, Jakarta.

Rangkunti, Freddy. 2002. Riset Pemasaran. Jakarta: PT Gramedia Pustaka Utama.

Roberts, Mary L., 2003, Internet Marketing: Integrating Online and Offline Strategies, International Edition, New York, Amerika: McGraw-Hill/Irwin.

Santoso, Singgih dan Tjiptono, Fandy. 2001, Riset Pemasaran, PT.Elex Media Kompitindo.
Sejahtera, Nehemia Handal. 2010. Analisis Pengaruh Experiential Marketing Terhadap Loyalitas Pelanggan. Skripsi Fakultas Ekonomi. Universitas Diponegoro: Semarang. Sidharta, Lani, 2004. Internet, Informasi Bebas Hambatan, PT. Elex Media Komputindo, Yogyakarta.

Sugiyono, 2002, Metode Penelitian Bisnis, Alfabeta, Bandung.

Widayat, 2004, Metode Penelitian Pemasaran, UMM press.

Wikipedia; Juni,3,2012. Facebook. http:// id.wikipedia.org/wiki/Facebook, diakses juni,6,2012.

Tribunnews; Februari,2,2012. Indonesia tempati posisi ketiga dalam penggunaan facebook. http://www.tribunnews.com/2012/02/02/ indonesia-tempati-posisi-ketiga-dalampenggunaan-facebook, diakses Maret, 7, 2012 